\title{
European Neighbourhood Policy in the Function of International Dispute Settlement
}

\author{
Jonida Mehmetaj \\ Lector, "Ismail Qemali" Vlora University, Albania \\ Email: mehmetajjonida@gmail.com
}

\author{
Doi:10.5901/ajis.2015.v4n2p53
}

\begin{abstract}
This study aims to analyze the role of the European Union in international dispute settlement, focusing on the European Neighbourhood Policy. The study includes an analysis of the Article 8 of the Treaty on European Union, the position and placement of this provision in the European Union Treaties after the Lisbon Treat as well as the comparison of this new settlement's previous position of Article 8 of the TEU and its new reflections. The legal framework provides a broad perspective on the relationship of the Common Foreign and Security Policy with the European Neighbourhood Policy. This study will focus on: the reasons for the inclusion or not of this policy in the Common Foreign and Security Policy; the analysis whether the European Neighbourhood Policy has a common goal with the Common Foreign and Security Policy for resolving international conflicts; and it will also investigate the main aim of this policy, if it is the international or neighborhood disputes settlement, or conflict resolution is simply a random placement of this Policy. Furthermore, an important issue to be addressed is whether or not representing the European Neighbourhood Policy is an effective mechanism for resolving disputes, if there was an effective instrument in concrete conflict resolution presented to recent years.
\end{abstract}

Keywords: European Union, European Neighbourhood Policy, Article 8 of TEU, Common Foreign and Security Policy, international disputes settlement.

\section{Introduction}

In 2003 the European Union, in order to protect the security and promote its values through the European Security Strategy established three strategic objectives. Firstly, addressing the threats; secondly, construction of security in its neighbours; and thirdly, building international order based on effective multilateralism (European Council, 2003). The second strategic objective sets out the basis for the development of the European Neighbourhood Policy in 2004. The main purpose of which was to address the new challenges that the European Union will face after the recent rounds of enlargement and strengthening the prosperity, security, stability as well as the democratic values (European Council, 2003).

In June 2003, the Council for General Affairs and External Relations noted the importance of "common responsibility for conflict prevention and conflict resolution" (GAERC, 2003, p. 33), between the partners of European Neighbourhood Policy and the EU. It was conceived in advancing to support foreign policy objectives of the EU (Commission, 2004a), (Hillion, 2013, p. 2). To be sure, the Commission underlined the ENP the full accordance with the objectives of the European Security Strategy 2003, where, "the task of the EU is to promote a network of well-governed countries in the European Union and East Mediterranean borders which can enjoy close and cooperative relations" (High Representative of CFSP, 2003).

Union enlargement with ten former communist countries created the danger of division of Europe into two camps, a highly developed Europe and other overseas poor. As Bindi states, "the danger was that of creating a two-speed Europe, with a firmly integrated, stable, rich in the West and a less stable, poorer, less democratic in the East" (Bindi, 2010, p. 99). This division was against the values that protect the Union, in its perception as an important global actor. Thus, to avoid the fear of potential instability and the threat of crises and conflicts among neighbours regionally and beyond, the Union considered the creation of new effective policies to prevent these as European Neighbourhood Policy.

To better understand the impact of the European Neighbourhood Policy in dispute resolution, we will look at how the legal framework of this policy is defined in the EU Treaties. Conception that this policy will eventually bring a solution and a zone of peace and prosperity, between the Union and neighbouring countries would be wrong. Through the interpretation of Article 8 of TBE, we will see that the role of the Union in conflict resolution will be conditional on Union cooperation and ability to cope with such situations. Relying on this analysis we will see whether this policy is an efficient or inefficient mechanism to resolve disputes and conflicts in neighboring countries. 


\section{European Neighbourhood Policy under Article 8 of TBE}

The Treaty of Lisbon is one of the most important Treaties established by the European Union in terms of institutional arrangements towards resolving international disputes, creating legal frameworks also in terms of establishing safer and stronger relationships with neighboring countries. Significant changes were made to the European Neighbourhood Policy, with the approval of the Treaty. Like all external action policies and increasing the role of the European Union in resolving international conflicts and disputes, the Treaty of Lisbon again tried to create new competences to the European Union in view of good European Neighbourhood Policy. European Neighbourhood Policy, treated by many authors, in political science as well as in law science, Blockmans, Łazowski (2006), Wessel (2011), Diez (2004), Vooren (2009), Cremona and Hillion (2006), occupies a central place in the EU's relations with its neighbouring countries, in different areas, but mainly in conflict resolution. To better analyze European Neighbourhood Policy, we will have a look at its legal framework or legal basis, which is focused on the following provisions:

- Article 8 of the Treaty on European Union.

- Title V, General Provisions for Foreign Action and the provisions of Common Foreign and Security Policy; including provisions from the Article 21 to the Article 46.

- Articles 216-219 (international agreements) and Articles 296-207 (market) of the Treaty on the Functioning of the European Union.

The study will focus only on the interpretation of Article 8 of TBE, which is the article which provides either directly European Neighbourhood Policy or the relationship of this provision with conflict resolution. Provisions which belong to External Action are provisions that directly address the Union's role in resolving the dispute, the Union as an international actor, but slightly detached from the European Neighbourhood Policy. While, in terms of TFEU articles, are these articles those that address different areas of the European Neighbourhood Policy, unlike the purpose of the study, for this reason the analysis will be developed under Article 8 of TEU.

The Lisbon Treaty introduced a new provision, Article 8, in TEU, giving a constitutional status (Hanf, 2011, p.2) to the relations of the Union and its neighbours by December 1, 2009. Article 8, of TEU is the article which deals directly with European Neighbourhood Policy, it has provided a new and specific legal basis, so that to conclude agreements between the EU and neighboring countries on various issues that affect and resolve the conflict. Article 8 of the Treaty on European Union states that:

"Union builds a special relationship with neighbourhood countries, with the aim of creating an area of prosperity and good neighborliness, based on the values of the Union and characterized by close relations and peaceful cooperation".

The aim of the Union was to ensure a common security in the region, between neighbouring countries and the Union. In case of conflict, crisis, but also in a normal situation neighbourhood states will decide the stability, democracy, security and peace by taking into account the cooperation and commitment in these agreements. Despite the hopes raised by the provisions of Article 8, of the Treaty on European Union, as stated in this policy so far and also as noted by various authors, in particular Michelle Comelli (2014), these provisions have never been used as a legal basis for connection of new agreements with those countries, as it was assumed in Article 8, paragraph 2, according to which:

"The Union may conclude specific agreements with relevant countries. These agreements may contain reciprocal rights and obligations as well as the possibility of undertaking joint activities".

Given the fact that the Union may conclude specific agreements, defines a "binding statement" (Hillion, 2013, p.3), which includes the obligation of the Union to develop such a relationship (Hillion, 2013, p.3). So, as defined in Article 8, of the TEU, the Union may conclude "special deals", implies that normally an agreement entered into, by two parties, perceives not only the commitment of one party but both of them, and the case of Union cannot only take on commitments which go beyond its competences. The Union can last as long as it finds support and reliability of the other party; in this case the parties do not enter into a conflict. But if the parties are immersed in conflict and do not take into account the requirements, advice and assistance of the Union, then Union engagement run down, because as mentioned above, the basis of this policy is the agreement. In order for that to be efficient it should be balanced on both sides with the utmost commitment for the solution of conflicts and disputes that these countries have with other states or civil wars within their own country. 


\section{European Neighbourhood Policy and the Common Foreign and Security Policy}

In the context of resolving conflicts and disputes between neighboring countries, Article 8, of the TEU, stresses "the creation of an area of prosperity" and "peaceful, close relationship cooperation". This way will be understood that this provision regulates and aims to regulate the relationship between neighboring countries, relationships that avoid situations of conflict and instability. On the basis of these close relations of good neighbourliness, countries will feel more secure and away from the threat of terrorism and violent conflict. Article 8, of TEU, finally determines the creation of a genuine legal basis by which the European Neighbourhood Policy could function as an effective mechanism for resolving disputes.

But the question that arises here is whether it could have really accomplished legal basis in reality? This is a controversial question, because the definition of the legal framework referred to in Article 8, of TEU, differs from the creation of a safe, stable and prosperous neighbourhood. Despite the practical implementation and security guarantees should also be noted the entire legal framework, previously established by the adoption of the Lisbon Treaty, defined as policy governed by "soft law instruments" (Comelli, 2014) and this expression supports almost all academics who treat European Neighbourhood Policy. The way the commitment of the European Union is formulated and its binding character, as well as the nature and type of conflict or problems of a certain state, determine the method to be applied in order to solve the conflict.

Article 8, of the Treaty on European Union has its origins in the Constitutional Treaty for Europe respectively in Article I-57, in the first half, as a separate article entitled "The Union and its neighbours". While Article 8, TEU, is inserted into the joint bylaws of the Treaty on European Union. European Neighbourhood Policy and mostly legal basis set out in Article 8 of TEU, is our chapter of the Common Foreign and Security Policy, which states that the neighborhood policy should not be affected by the Common Foreign and Security. Setting this policy outside the provisions of the Treaties on "External Action EU", suggests that the power of the neighbourhood are conceived as a policy with both dimensions, in internal and external dimensions (Hillion, 2013, p.3). Exactly the two dimensional character, internal and external of this policy makes European Neighbourhood Policy not an efficient mechanism for resolving disputes, as conflict resolution is just one of the areas of activity of this policy. What makes it to be far from the solution of disputes and conflicts between neighboring countries is its comprehensive character.

But the reason, if this shift is an accident in the Lisbon Treaty drafting, or a deliberate choice remains, controversial (Hillion, 2013, p.2). Different conceptions are given on this fact, taking into account its comprehensive character. Te comprehensive character of European Neighbourhood Policy can be one of the reasons, why it is left out of the Common Foreign Policy and Security and is regulated in a special provision in the common provisions of the Treaty on European Union.

\section{European Neighbourhood Policy and Conflict Resolution, Effective Mechanism or Not?}

The main contribution of this policy consisted of establishing international peace through the promotion of local democracy, regional cooperation and socio-economic progress, which could indirectly contribute to ensuring a positive safety climate for resolving international disputes (Blockmans, and Wessel, 2011). In the strategic document of the European Neighbourhood Policy in 2004, the Commission shows its ambition and a serious commitment by defining specific areas of activity of this policy beyond the political dialogue. Serious commitment to bring defined security elements in concrete and other issues beyond the political dialogue set up at the moment, but issues pertaining to dispute resolution, specifically, in matters such as the consolidation of relations between the Union and its neighbours in terms of the Common Foreign and Security Policy of conflict prevention, crisis management, information sharing, joint training and participation in operations management the EU-led crisis (European Commission, 2004b).

Taking into consideration the aspects of the Common Foreign and Security Policy on prevention, crisis management and conflict were created in order to prevent the main threats which were listed in the European Security Strategy of 2003. Among the major threats listed here were terrorism, proliferation of weapons of mass destruction, state failure, organized crime and regional conflicts. Conflicts in the borders of the EU, are dangerous not only for the countries involved in the conflict but also for the region and even for other regions. Because the threatened regional stability and conflicts can lead to extremism, terrorism and organized crime (European Commission, 2004b), the escalation which later can be very difficult and long to resolve. Problems like those of Kashmir, the Korean Peninsula and above all the Middle East, directly or indirectly affect European interests (European Counsil, 2003, p. 3).

In 2010-2011, the EU has reviewed European Neighbourhood Policy, placing the focus of this policy, the promotion 
of democratic principles, a democratic system, ensuring close relations between the neighbouring countries. Mainly sixteen nearest neighbours of the EU, in order to establish a deep democracy and sustainable, focused on the free elections and fair elections, freedom of expression, assembly and association, independence of judiciary, fight against corruption and control democratic over the armed forces.

Conflicts and disputes in neighbouring countries are present and evident in their most outrageous. One such case is the conflict in Ukraine, "the dramatic events in Ukraine have demonstrated how an uncommitted government disconnected from broader feelings of the population and subject to unacceptable external pressure can provoke political and social disturbance" (European Commission 2015c, p.3). Highlighting the conflict with Ukraine, under the Communication, Ukraine is one of five countries of the European Neighbourhood Policy that has concluded a framework agreement for participation in crisis management operations of the EU. In April 2010, the Council authorized the High Representative to open negotiations with a view to conclude such agreements with twenty other countries, among which were Egypt and Morocco as the only countries in the European Neighbourhood Policy (Council conclusions 2010), (Blockmans and Wessel, 2011). Besides Ukraine there are other conflict in neighbouring countries, for example, in Southern Neighbourhood, the actions of some regional or global actors have influenced the political and economic conflict in Syria and the crisis in Egypt (European Commission 2015c, p.2).

In the Communication of the European Commission in 2014, was also noted that, "once again, was a year of crisis, reflecting political instability and continued difficult socioeconomic conditions across a number of countries" (European Commission 2014c, p.2). The situation in the region and the European Union neighbours is still tense, it's important to mention here, the crisis in Georgia in 2008; the conflict in Ukraine, disputes that have affected the aggravation of relations between Russia and the EU. Conflicts caused by the civil situation in Syria in 2011, the ongoing conflict in Libya, Gaza, etc. The existence of so many conflicts and crises made questionable the role of the Union to effectively resolve these conflicts and disputes, in case of the European Neighbourhood Policy as an efficient mechanism.

From what we saw above, despite the mechanisms, instruments, policies and action plans that set up the European Union to ensure security and dispute settlements, conflicts were again present at the regional and global order more than ever. For this reason, supporting the idea of other academics we can say that, despite the efforts, the Union could not achieve a great deal among its neighbours and establish lasting relationships. This is partly due to the fact that the agenda for the implementation of ENP objectives is determined by both the EU, on one hand, and the respective partner country, on the other one (Blockmans and Wessel, 2011).

The European Neighbourhood Policy is a comprehensive character, as this policy except for conflict resolution which is only one of its goals, directed also to energy policy, environmental policy, agriculture, development of the internal market, research and innovation, support in health, education, culture and of course, in the process of expanding neighbouring countries.

Due to their comprehensive nature, the European Neighbourhood Policy is not part of the provisions of the Common Foreign and Security Policy. Furthermore, Benita Ferrero Waldner, former commissioner in external relations and European Neighbourhood Policy has noted that "the European Neighbourhood Policy in itself is not a mechanism for preventing or resolving conflicts," however the policy focuses on a direct contribution for stability in the European Union Neighbourhood (Blockmans and Wessel, 2011). The concentration of stability is the term which includes terms of conflict resolution, the willingness and ability of the Union to be important and to provide effective solutions.

\section{Conclusions}

In conclusion we can say that the European Neighbourhood Policy is not an effective mechanism for resolving international disputes. Resolving conflicts, disputes and crises remains one of the biggest challenges of the European Union; its efforts in this direction are continuously recorded. But policy coordination, power, mechanisms and legal framework applied remain difficult to be realized successfully. Despite significant changes in realization of the European Neighbourhood Policy after the Lisbon Treaty, the European Union still has had difficulty resolving disputes and conflicts. This is verified by the existence of a large number of conflicts and crises in the region and neighboring EU countries. The Lisbon Treaty introduced a new provision, which is the Article 8 in TBE; this provision governs the relationship between the EU and neighbouring countries in building a climate of peace and safe. However, this provision does not serve as a legal basis for regulating relations with neighboring countries and close connection agreements by both parties.

The perception of the European Neighbourhood Policy as an indirect mechanism, ineffective in resolving disputes has been affected by several elements. These elements may be, this policy's two-dimensional character, internal and external dimension, the exclusion of Article 8 of TBE in the EU's Common Foreign and Security Policy, the commitment 
of implementing agreements between the Union and neighbouring countries, the lack of binding character of the Union and of this policy too. Also the inclusive character of this policy, is another important element which removes this policy from the conflict resolution as its primary purpose.

\section{References}

Balcer, A. (2013). The EU and Turkey in the Southern Neighbourhood: A new opening? Notre Europe - Jacques Delors Institute, demosEUROPA, Policy Paper, No. 72.

Balzacq, Th. (2009). The External Dimension of EU Justice and Home Affairs Governance, Neighbours, Security, USA: Palgrave Macmillan.

Bindi, F. (2010). The Foreign Policy of the European Union, Assessing Europe's Role in the World, Washington, D.C: Brookings Institution Press.

Blockmans, S. and Łazowski, A. (2006). The European Union and Its Neighbours: A Legal Appraisal of the EU's Policies of Stabilisation, Partnership and Integratio. The Hague: TMC Asser Press.

Blockmans, S. and Wessel, A. R. (2011). The European Union and Peaceful Settlement of Disputes in its Neighbourhood: the Emergence of a New Regional Security Actor? In, The European Union and Global Emergencies: A Law and Policy Analysis. Modern Studies in European Law. Hart Publishing, p. 73-103.

Casier, T. (2008). "The New Neighbors of the European Union: The Compelling Logic of Enlargement". In the Boundaries of EU Enlargement. Finding a Place for Neighbors, edited by Joan DeBardeleben, Basingstoke, UK: Palgrave Macmillan.

Comelli, M. (2014). Article 8 TEU and the Revision of the European Neighbourhood Policy, in Amending or Coping with the Existing Treaties? Rossi, L. S. And Casolar, F. The UE after Lisbon. Springer International Publishing, p. 267-289.

Cremona, C. and Meloni, G. (2006). The European Neighbourhood Policy: A Framework for Modernisation? Italy European University, EUI Working Paper LAW, No. 39.

Dannreuther, R. (2004). European Union Foreign and Security Policy, Towards a neighbourhood strategy. New York: Routledge.

Elsuwege, V. P. and Petrov, P. (2001) Article 8 TEU: Towards a New Generation of Agreements with the Countries of the European Union? European Law Review, Vol. 36, p. 688.

European Commission and High Representative, (2011). A new response to a changing Neighbourhood. Brussels.

European Commission and High Representative, (2011). A partnership for democracy and shared prosperity with the southern Mediterranean. Brussels.

European Commission, (2004). Communication on the European Neighbourhood Policy, Strategy Paper. Brussels.

European Commission, (2004a). European Neighbourhood Policy, Strategy Paper, 373 final.

European Commission, (2004b). A more effective political dialogue. Brussels.

European Commission. (2014c). Joint Consultation Paper, Towards a new European Neighbourhood Policy. Brussels.

European Counsil. (2003). A Secure Europe in a Better World, European Security Strategy, Brussels.

GAERC, (2003). Council Conclusions, Press Release no 10369/03, Presse 166, 33.

Ganzle, S. and Sens, G. A. (2007). The Changing Politics of European Security Europe Alone? USA: Palgrave Macmillan.

Geoffrey Edwards, G. (2008). The Construction of Ambiguity and the Limits of Attraction: Europe and Its Neighborhood Policy, Journal of European Integration 30, No. 1, 2008, p. 45-62.

Hanf, D. (2011). The ENP in the light of the new "neighbourhood clause" (Article 8 TEU), College of Europe, Research Paper in Law Cahiers juridiques, No. 2.

High Representative of CFSP, (2003). A secure Europe in a better word, European Security Strategy.

Hillion, C. (2013). The EU Neighbourhood competence under Article 8 TEU. Swedish Institute for European Policy Studies.

Holzhacker, L. R. and Luif, P. (2014). Freedom, Security and Justice in the European Union, Internal and External Dimensions of Increased Cooperation after the Lisbon Treaty. New York: Springer.

Kelley, J. (2006). New Wine in Old Wineskins: Promoting Political Reforms through the Neë European Neighborhood Policy, Journal of Common Market Studies 44, no. 1, p. 29-55.

Keukeleire, S. and MacNaughtan, J. (2008). The Foreign Policy of the European Union, Basingstoke, UK: Palgrave Macmillan.

Kleenmann, K. (2010). The European Neighbourhood Policy - A Reality Check How effective is the European Neighbourhood Policy in promoting good governance? Romanian Academic Society.

Sasse, G. (2008). The European Neighborhood Policy: Conditionality Revisited for the EU's Eastern Neighbors, Europe-Asia Studies 60, No. 2, p. 301.

Smith, K. (2005). The Outsiders: The European Neighborhood Policy, International Affairs 81, no. 4, p. 757-73.

Smith. E. M. (2004). Europe's Foreign and Security Policy The Institutionalization of Cooperation, New York: Cambridge University Press.

Thomas Diez, Th., Albert, M. and Stetter, S. (2004) The European Union and Border Conflicts The Power of Integration and Association, New York, Cambridge University Press.

Treaty of European Union

Vooren, V. B. (2009). The European Neighbourhood Policy as a Case-Study for Soft Law in EU External Relations, European Law Review, Vol. 34, No. 5, p. 696. 
